\title{
Editorial
}

\section{The era of virtual reality in medical education: do we still need the dissection table?}

\author{
Vivek Parameswara Sarma*
}

Department of Paediatric Surgery, SAT Hospital, Government Medical College, Thiruvananthapuram, Kerala, India

Received: 26 November 2020

Accepted: 09 January 2021

\section{*Correspondence:}

Dr. Vivek Parameswara Sarma,

E-mail: vivsarma@gmail.com

Copyright: (c) the author(s), publisher and licensee Medip Academy. This is an open-access article distributed under the terms of the Creative Commons Attribution Non-Commercial License, which permits unrestricted non-commercial use, distribution, and reproduction in any medium, provided the original work is properly cited.

For the benefit of the uninitiated, the MBBS course begins with the three basic subjects, anatomy, physiology and biochemistry. Of these, the most intensive and gruelling for most is the subject of anatomy. And within the said subject, the most demanding is the human dissection table. It can even be considered as the ultimate icon of initiation into medical education. It has tragedy, dark comedy and drama in different measures. The image of young students huddled around a shrivelled human body, usually referred to medically as a 'Cadaver, on a non-descript table, ever endures in mind of all doctors, for better or worse. This happens in a hall ever filled by the suffocating smell of formalin and the dread of the watchful eye of demonstrators trained like hounds. The course in anatomy is split into different sections on limbs, thorax, abdomen, head and neck etc, with corresponding dissection studies to be made on the cadaver, which shall henceforth be referred to as the 'body'.

It is a very rare student that is not awed or overwhelmed initially by the presence of a 'body' in the midst of proceedings. There is an initial reluctance to even see, which is followed by 'steal' glances and then a gradual acceptance of the necessity to observe. The dehumanised state of the body slowly sinks in and one hesitantly moved closer. The worst though, is yet to come. One has to cut open the body to see the internal structures, viscera, vessels, nerves, muscles and the works! The brave or the foolhardy get going first, reluctantly followed by the rest. Some never make it there though. There are many who will vouch to have never touched the body even with a barge pole, forget the scalpel, other than for the exam. This air of dread is an intricate part of the secret life of every medical student worth his salt. The act of initiation into the field of medicine becomes a ritual of dehumanisation, instead of being one of compassion. The bizarre truth is that the culture of 'dissection hall dread' is passed down from one generation to the next and the resultant scars worn as badges of pride.

If one thinks that the worst is over, not yet. Osteology involves study of the bones, and involves possessing a 'bone set', if not individually, at least for a group. The peon in the demonstration hall fixes a rate for the set after some haggling, and then one repents having even got it to begin with. The dreadful box is kept under the bed in most cases, as there is hardly any other space available. The fertile imagination of the young mind takes care of the rest. One's mind obstinately keeps working out probabilities like cause of death and how the set was obtained from the cadaver in first place. The set is religiously passed on to the next unsuspecting pupil! If one is eager for more, left still are experiments on 'lower life forms' (?!) like frog and rabbit in the guise of elaboration of physiological principles! The department of Biochemistry benevolently spares one of any such mutilation, more likely because the innate horror of the subject itself usually suffices to that very end.

There exists an unfortunate side for the story though. The act of dissecting the cadaver, in many instances, fails to achieve the very purpose it was designed for, to teach human anatomy. The tissue preserved in formalin is so desiccated that vessels and nerves become indistinguishable. One might as well flip a coin to give an opinion. Many a young mind is rendered too numb by the spectre to care if it is fascia, tendon or muscle!! Worst still is the fact that the art and science of exposition and exploration of the beautiful machine that human body is, becomes an abhorrent, ritualistic and morbid act for the majority. In place of kindling a spirit of inquisitiveness, it successfully drives out, most of the students from any 
greater pursuit of understanding the wonderful mechanisms involved.

Where is the answer though? In recognition of the fact that the coming generations will value the dignity of human body, only when their teachers do so. The method lies largely in virtual reality (VR) and augmented reality (AR). VR and AR are being increasingly employed in medical education. ${ }^{1-3}$ Where better than in teaching the fundamentals of anatomy, principles of physiology and intricacies of biochemistry? The three dimensional and colourful images of the finer details of human anatomy can be taught with utmost ease for deeper understanding. Many such programs are already available along with text books or randomly on the internet, even free of cost. The discerning teacher can compile the necessary information and apt imagery to create a VR show of great clarity. The course of nerves, the vascular arches and foramina of skull will surely make more sense to the audience in such a show. If a picture is worth a thousand words as they say, then a video should be worth at least a million! One of the most astounding use of VR can be in the teaching of human developmental embryology, which is difficult to grasp in two dimensional images. The creative possibilities of VR can be used for everything from the microscopic demonstrations of histology to the basics of medical genetics.

Where are we trapped though? A medical professional is bred to be a status quoist by default. The ones questioning are usually scorned. One thus learns to live within the existing framework, and expects the ones following to fit in. Anything on the contrary is considered sacrilege, and no less. And to make it worse, there is no inbuilt corrective or adaptive mechanism that periodically modifies the system to suit the needs of the time. Hence, in spite of the availability of all technological advancements at hand, no system is in place to make it available for the student. VR-based techniques have tremendous potential to replenish and revolutionize basic medical education, in almost every course from fundamentals to specialities. ${ }^{4-10}$ The tremendous opportunity is unfortunately yet to be explored in a structured manner.

The human side of the story is still untold. As a training medical professional, one of the greatest truths to imbibe is the dignity and sanctity of the human body. The existent mechanisms to obtain, preserve and ultimately discard the 'body', are actually well within the scope of this article, but unsuitable for publication in anything other than a journal of horror, if ever there was one. If the reader has assumed anything by now, it can be assured that the reality is infinitely worse. Whether there by default, option or deceit, our responsibility is to treat the human body with grace. This would serve as a noble first lesson, in the life as a doctor, for the newly initiated. What was relevant and important in one age need not be necessary in another. What was designed with a noble purpose at one time may not be required any more at another. What was necessary at one time may be unfair and even unethical at another. The crux is the willingness to identify and accept what needs to be changed. The elucidation of learnings on human body to the next generation needs to be vivid, imaginative and enthralling, while appreciative of the sanctity of the human body. It is a collective responsibility that medical teachers of this generation cannot shy away from or fail in.

\section{REFERENCES}

1. Nicholson DT, Chalk C, Funnell WRJ, Daniel SJ. Can virtual reality improve anatomy education? A randomized controlled study of a computergenerated three-dimensional anatomical ear model. Medical Education. 2006;40:1081-7.

2. John NW. The impact of Web3D technologies on medical education and training. Computers Education. 2007;49:19-31.

3. Lai CM, Huang HM, Liaw SS, Huang WW. A study of user's acceptance on three-dimensional virtual reality applied in medical education. Bull Edu Psychol. 2207;40(3):341-62.

4. Temkin

B, Acosta E, Hatfield P, Onal E, Tong A. Web-based three-dimensional virtual body structures: W3DVBS. Am Med Informatics Association. 2002;9(5):425-36.

5. Levinson AJ, Weaver B, Garside S, McGinn H, Norman GR. Virtual reality and brain anatomy: A randomised trial of e-learning instructional designs. Med Education. 2007;41(5):495-501.

6. Lu J, Pan Z, Lin H, Zhang M, Shi J. Virtual learning environment for medical education based on VRML and VTK. Computers Graphics. 2005;29:283-8.

7. Chittaro L, Ranon R. Web3D technologies in learning, education and training: Motivations, issues, opportunities. Computers Education. 2007;49:3-18.

8. Chow M, Herold DK, Choo TM, Chan K. Extending the technology acceptance model to explore the intention to use Second Life for enhancing healthcare education. Computers Education, 2012;59:1136-44.

9. Brenton

$\mathrm{H}$,

Hernandez J, Bello F, Strutton P, Purkayastha S, Firt h T, Darzi A. Using multimedia and Web3D to enhance anatomy teaching. Computers Education. 2007;49:32-53.

10. Weibel D, Stricker D, Wissmath B. The use of a virtual learning centre in the context of a university lecture: Factors influencing satisfaction and performance. Interactive Learning Environments. 2012;20(1):77-87.

Cite this article as: Sarma VP. The era of virtual reality in medical education: do we still need the dissection table? Int Surg J 2021;8:771-2. 